\author{
Raimundas Lopata* \\ The General Jonas Žemaitis Military Academy of Lithuania ${ }^{* *}$
}

\title{
Kaliningrad in the European Security Architecture after the Annexation of Crimea
}

Following Russias aggression towards Ukraine and the occupation of Crimea, there are few who would doubt Moscow's endeavours to influence the balance of power in the pan-Baltic region as well. As often as not, such endeavours tend to be analysed after they occur. Russia's potential to exercise this kind of influence using the Kaliningrad factor was recalled as if apropos of nothing. This is cause to suspect that academic research has so far failed to properly consider Kaliningrad as a geostrategic factor.

Then there are the questions: What is the course of the transformation of the geopolitical status of the Russian Federation's Kaliningrad (Konigsberg) region? What is the role that Moscow has earmarked for the exclave within the European security architecture? And is it a merely regional role? One way to find out the answers is by verifying the governance model applied by the parent country to the oblast, which is convincingly grounded on the concept of a geopolitical hostage.

Moscow is tightening its grip on the social, economic and political processes in Kaliningrad. By using financial subsidies, infrastructural projects and laws to modify the status of the exclave, it is trying to stabilise the socio-economic situation in the exclave, making every effort to ensure Kaliningrad's viability under isolation and transit restriction (termination). Political control is assured by Moscow's direct dummies within the exclave's administration and United Russia's dominance at so-called elected institutions.

After the war with Georgia, which is to say roughly since 2009, Russia has taken focused steps to rapidly modernise and reorganise its military. As we analyse the measures Russia deploys to develop its military presence in the Western Military District, we can say that in 2015-2016 Moscow attained the complete superiority of conventional weaponry over NATO. The Kaliningrad region played a vital role in that process. Both implicitly and for all practical purposes, the exclave became a factor to perform the function of Russia's military bastion. Strategically speaking, this is the region's old role given new life.

Kaliningrad has become the heart of Russia's A2/AD 'bubble', raising new challenges for the security of the Scandinavian countries, Finland, the Baltic states and Poland, ergo Western Europe. Kaliningrad has turned into a diminishing factor in terms of Belarus' geopolitical role. The consistent re-militarisation of Kaliningrad affects the regional states and transatlantic relations alike. Moscow's goal is for the Kaliningrad factor to be of strategic importance in the balance of power dialogue with the West, and the US in particular. Moscow is being frank that the purpose of a remilitarised Kaliningrad in the Baltic region and the Kuril Islands in the Far East is to reduce the geostrategic influence of the US and increase Russia's security beyond the perimeter of its borders.

\footnotetext{
* Raimundas Lopata, PhD, is a professor with the Institute of International Relations and Political Sciences of Vilnius University, mailing address: Vokiečių 10, 01130 Vilnius, phone: 8-5-251-41-30, e-mail: raimundas.lopata@tspmi.vu.lt.

** This study was commissioned by the General Jonas Žemaitis Military Academy of Lithuania. Contract no. 8P-8, 13 November 2017.
}

DOI: 10.2478/lasr-2018-0011

(C) Raimundas Lopata, 2018

(C) Military Academy of Lithuania, 2018 


\section{Introduction}

The shift in the balance of power in the pan-Baltic region that began in wake of Russia's military intervention in Ukraine and the occupation of Crimea is forcing us to rethink the geopolitical status of the Russian Federation's Kaliningrad region and its place within the European security architecture.

It is worth remembering that the problem that has long been referred to as the Kaliningrad puzzle is geopolitical in terms of its source and originality. It can be briefly described as follows. The part of East Prussia that fell into the hands of the Soviet Union after World War II was turned into a gigantic soviet military base. It acted as a forward-post against the West and a barrier that helped the USSR secure the dependence of the eastern Baltic region and dominance in Poland. A domain of the Russian Federation since after the Cold War, this westernmost $15,000 \mathrm{sq}$. km territory with population of nearly one million, despite having access to the Baltic Sea, on the landside was separated from its parent country and became an exclave (or rather, semi-exclave). The exclave gradually found itself at a crossroads of differing security structures and eventually became encircled by one of them (the Euro-Atlantic one). The changes in the situation have brought forth the so-called discourse of Kaliningrad studies: political decisions and academic discussions and studies (R. D. Asmus, S. Browning, S. Dewar, D. Fairlie, P. Holtom, P. Joenniemi, R. Krickus, Č. Laurinavičius, R. C. Nürick, I. Oldberg, A. Sergiunin, V. Sirutavičius, I. Stanyté-Toločkienè, C. Welmann, and so on) affected by the shift in international policies in Central and Eastern Europe as well as the interior transformation of the USSR/Russian Federation, regarding the role of the Russian exclave in East-West relations and its place in Russias foreign and interior politics ${ }^{1}$.

\section{Problem-oriented Fields of Research}

The range of interpretations on the subject of the Russian Federation's Kaliningrad region is quite vast in academic literature. Notably, issues coming into the exploratory spotlight such as how the USSR collapse affected Kaliningrad's situation, what will become of it in the future, what the role of the parent country and its neighbours will be, how it will be affected by the eastbound Euro-Atlantic expansion, how the international community should help the

\footnotetext{
${ }^{1}$ Lopata R. (2006), Rusijos Federacijos Kaliningrado srities geopolitine transformacija. Habilitacijos procedūrai teikiamų mokslo darbų apžvalga, Vilnius: Vilnius University, p. 6.
} 
exclave adapt to the changing environment, and so on, often went hand in hand with the transformations of post-Cold-War East-West relations. As these relations were basically marked by a search for a new security architecture, the subject of Kaliningrad became dominated by a trend to overcome insecurity, 'a threat potentially encoded in the oblast'.

Its dissemination could be split relatively into certain phases. In the late 1980s and early 1990s, the trend was reflected by texts modelling the future of the Kaliningrad region on the basis of the Potsdam tail and dealing with the military threat that the exclave poses to the security of the pan-Baltic region.

In roughly the mid-1990s, the idea of Kaliningrad as a Baltic Hong Kong was launched along with various suggestions to internationalise and demilitarise the exclave. The idea was aimed at revealing the potential of the exclave as a possible economic bridge or link between East and West.

At the turn of the century, practical steps towards reducing the level of the exclave's militarisation were followed by a strengthening of focus in Kaliningrad studies on non-military threats. An increasing amount of attention was given to matters on the effect of the European Union's eastwards expansion on the social-economic development of the exclave, its lagging behind the neighbours and the consequences of its becoming a 'double periphery'. Recommendations to tackle this type of problem with the principles of organising the political space that formed the backbone of the EU multilevel governance logic and were disseminated through the expansion of the EU became highly popular.

Eventually, with Kaliningrad becoming surrounded by NATO and the EU, the rising tensions were tied to the practical and technical solutions of Russian passenger, goods and military transit to and from the region ${ }^{2}$.

And so the Kaliningrad region failed to become a factor to prevent the further expansion of the Euro-Atlantic institutions. It did not cause a military conflict as was sometimes predicted, and finally did not become a 'black hole' in the context of so-called soft security - a centre for the socio-economic destabilisation of the Baltic region, something that has been written and spoken about a lot. In other words, we could say that the Kaliningrad wheel is moving forwards, inspiring thoughts of progress after every cycle.

On the other hand, the optimistic scenario, one that called for unconventional solutions to the existing situation and drew an outline of free trade, vast autonomy and the exclave's clear freedom to act, has failed as well. The academic discussions on whether the process of the Western and Eastern

\footnotetext{
${ }^{2}$ For more, see Lopata (footnote 1), p. 13-18.
} 
structures overlapping in this part of the Baltic Sea region has virtually neutralised the 'potential threat encoded' in the exclave are still ongoing. Of course, prior to Russia's aggression towards Ukraine it had not been very active and revolved around dated topics. In other words, the discussion is still trying to answer the question: Does the exclave has the potential to become a centre of instability, considering its historical, cultural, social-economic and geopolitical characteristics, or does it have the potential to become a pilot region for partnership between the West and Russia?

As a case in point, a collective monograph titled Crisis Management Challenges in Kaliningrad, which was issued a few years ago and was funded by the Swedish Defence College, discussed, from the historical perspective too, matters of the exclave's administrative, social and economic process management, as well as ecological threats ${ }^{3}$.

Poland and Russia signing an agreement to facilitate travel for borderland citizens in 2012 caused much joy about the positive nature of the accord. The Poles were rather bold in pushing the thesis that the exclave was no longer viewed exclusively through a pair of military binoculars, and that the changing relations between NATO, the EU and the Russian Federation could have a positive effect on the role of Kaliningrad in Polish-Russian relations. Radoslaw Sikorski, then Polish Minister of Foreign Affairs, was grateful: 'I thank Russian buyers, $[\ldots]$ our borderland voivodships that ended up being in the territory defined by the agreement have seen a $30 \%$ increase in sales ${ }^{4}$. The Poles were not thankful to Russia for long.

The process of the militarisation of Kaliningrad that became particularly evident after the 2014 Russian aggression towards Ukraine scattered all optimism. The terms military forepost, bastion and jumping-off ground that had been used several decades ago were reborn ${ }^{5}$. Talk about a very real military conflict began.

\footnotetext{
${ }^{3}$ Krasnov E., Karpenko A., Simons G., eds. (2016), Crisis Management Challenges in Kaliningrad, London and New York: Routledge, p. 215.

${ }^{4}$ Żukowski A., Modzelewski W. T. eds. (2016), Kaliningrad: Its Internal and External Issues, Olsztyn, Institute of Political Science University of Warmia and Mazury in Olsztyn, p. 81-92, 101.

${ }^{5}$ Agee Ch. (2016), 'Kaliningrad could be next flashpoint between Russia and the West', https://www.irishtimes.com/opinion/kaliningrad-could-be-next-flashpoint-between-russia-and-the-west-1.2845352, 2016-10-27 ; Sukhankin S. 'The Kaliningrad Oblast Today: A "Military Bastion 2.0", Not a Bridge Cooperation', https://www.diplomaatia.ee/en/article/the-kaliningrad-oblast-today-a-military-bastion-20-not-abridge-of-cooperation/ 25/06/2017.
} 


\section{Segments of the Kaliningrad File}

The Kaliningrad file consists of a string of combinations for the expression of the relationship between the parent country (the Russian Federation) and the geopolitically removed territorial fragment (the Kaliningrad region), affected by internal and international factors. Combinations of internal and external factors have been affecting the diversity thereof for more than fifteen years, and said diversity is tasking Russia with controlling the exclave in a rapidly shifting internal and international environment - a strategic objective. At the time that academia is persistently looking for future visions for the exclave, Moscow is handling matters that are much more pragmatic in nature. What complicates things for the parent country is the dilemma between the role that, in Moscow's opinion, is legally (po pravu) its own, and the role it is permitted to be performed by the exterior environment. In other words, Russia is forced to adjust its possibilities in enforcing one or the other strategy for the relationship with the fragment, adapting it to the changing environment both in and around the oblast. Failure in resolving the dilemma would open up a real opportunity for the exclave to distance itself from Moscow, without ruling out a scenario where the parent country becomes defragmented.

The biggest worry that parent countries have is the task of managing the strategic power to govern territorial fragments. It requires ensuring the security of separate regions, their adequate socio-economic development, communication with the regions, as well as focused efforts in moulding the loyalty of the denizens of the territorial anomaly to the centre. That is why in searching for ways to neutralise threats to maintaining sovereignty, parent countries often seek to establish within territorial anomalies an administration that would not impede the state's prevalent principles of political and territorial control, and make every effort to ensure effective communication with it ('ignoring the host state'). The role of the host state can be seen in its reaction to the parent country's actions aimed at securing communication with the exclave/enclave. And this, particularly when its relationship with the parent reaches the socalled level of 'high' politics, comes under the influence of the 'exclave/enclave syndrome'; if territorial formations like this are seen as specific or special but no specific measures are employed to realise the needs of its residents, eventually the territorial formation 'loses' its will to have a special status. In other words, when it comes to the above triangle, it is the parent country, its strategy and tactics with regard to the isolated territory that plays the leading part.

It was the interest to tighten the bond between parent country and excla- 
ve that determined Moscow's strategic line to make this region a geopolitical hostage, a territory that fell into its possession as spoils of war in the process of cession, in a bid to keep the territory (the interior aspect) and to make other countries and international institutions carry out or refrain from any direct or indirect act to liberate the hostage (the exterior aspect).

The practical development of this geopolitical hostage allows us to identify the segments (factors) that determine expressions of the relationship between the parent country (the Russian Federation) and the geopolitically separate territorial fragment (Kaliningrad Region):

-The strategic capacity and need of the Russian government to control the exclave:

- the legitimisation of the exclave's legal subordination to Russia;

- the efficiency of governance (administrative abilities, the financial dimension, the aspect of socio-economic modernisation, the issue of the exclave's self-identification);

- the military function of the exclave.

- The factor of other countries and international institutions in the issue of Kaliningrad.

- Ensuring a territorial link between the exclave and the parent country (matters of military, passenger and goods transit).

\section{Russia's Strategic Capacity and Need to Control the Exclave}

This factor basically defines the value of the Kaliningrad region as a security object to the Russian Federation. After the Cold War, the value of the exclave's territory was the product of a combination of several symbolic and strategic reasons.

Formally, the former were reflected by Russian political rhetoric on Kaliningrad/Konigsberg as a World War II trophy that was Russia's by right. However, deep down the rhetoric was grounded on the complications of the region's status from the standpoint of international law and the immediately related beating of the so-called Potsdam tail.

The second group were reflected by Moscow's hands-on attempts to exploit the exclave's geopolitical significance either by keeping the exclave as a military forepost against the West or by turning it into a gateway of Russia's 
structural approach towards the West or by allowing it to become Russia's geopolitical jumping-off ground (a passing pawn) in the European Union.

Notably, any kind of hands-on achievement of geopolitical significance for the exclave was inseparable not only from Moscow's efforts to legitimise its World War II acquisition and the attempts to control it efficiently by anchoring an institutional base that would guarantee the exclave's political, legal and economic stability.

Due to Kaliningrad's specifics (the Potsdam tail, the geopolitical situation, socio-economic and other factors), it is the interior aspect that may be of more relevance to Moscow, it being officially covered up by its exterior counterpart. In other words, Moscow has sought (and is seeking) to retain and consolidate the exclave's political subordination to the centre, at the same time as looking for ways to achieve its socio-economic modernisation that would prevent the exclave from falling behind its neighbouring countries dramatically at this level, as well as for ways to use the exclave as a diplomatic tool in international politics.

This political model towards the exclave on Russia's part is to be seen as an adequate key to the Kaliningrad puzzle ${ }^{6}$. It allows for overcoming the paradox that has been revealed in some of the research dedicated to Kaliningrad studies: the Kaliningrad issue has been established, but the Kaliningrad puzzle is yet to be resolved.

Formally, the external dissemination of the hostage mechanism has been illustrated by Moscow's game of two metropolitan strategies with regard to the exclave. Strategy number one focuses on the exclave's role as Russia's military forepost geared towards expanding the influence of the jumping-off ground and/or hamper the influence of the West, depending on the circumstances. Strategy number two sees the exclave as a testing ground for economic reforms (a 'pilot region') that could have become a geopolitical tie to link Russia and the West and facilitate economic and human exchange and the exchange of ideas thanks to its favourable geographical location. Yet in real diplomatic practice, the exclave has become some kind of collateral used in the strategic trade between Russia and the West based on a tactic of deterrence (suppression) - pacification and engagement. To put it in simple terms, the less NATO and US involvement there is in the region, the less Russian arsenal there is in the exclave and the more it is open to the processes of EU expansion and European integration. Yet this kind of Russian phraseology does not mean that Russia is abandoning the idea of using the exclave as a factor in exercising

${ }^{6}$ Lopata R. (2006), İkaito anatomija. Kaliningrado jubiliejaus byla, Vilnius: Eugrimas, p. 20-22. 
pressure and blackmail against Lithuania and at some point Poland; on the contrary: it is using the region to legitimise such acts. The twists and turns in the case of the so-called Russian military, passenger and goods transit is most likely the best evidence there is to support this statement ${ }^{7}$.

Formally, the interior proliferation of the hostage mechanism has been evident in the fate of the parent country's commitments to the exclave. Ever since the collapse of the USSR, turning the Kaliningrad oblast into an exclave, it has received quite a lot of commitment and binding promises from the centre. Yet the most critical of these were three. The federal centre declared it would ensure Russia's legal legitimacy, efficient governance and stable development in an exclave that has lost a territorial link with the parent country (the heartland). Moscow was positive that it had enough internal resources and instruments in its arsenal and that it was able to utilise external factors to deliver on these commitments. This is why it was willing to give the oblast hope of a new political and specific economic status (that of a Free Economic Zone (FEZ) or Special Economic Zone (SEZ)) in exchange for being an exclave, without actually having a strategic plan of how this would ensure the stable development of the region, and failing to grasp the extent and speed of international processes, and EuroAtlantic integration first and foremost, straight away.

This is why the parent country formally had no objections to, and even encouraged the treatment of, this province as a specific region. Yet in practice, it subdued the expression of its special nature. In doing so, it was trying to induce and maintain some kind of Stockholm syndrome in the exclave; Kaliningrad's denizens had to make peace with the status as an ordinary Russian region, with Moscow making every decision on the expression of the exclave, and the oblast itself banned any self-expression as a subject.

\subsection{Legitimisation of the Exclave's Legal Subordination to Russia}

After the USSR collapsed, the position of Kaliningrad as an exclave spawned specific political, economic and psychological tensions. What complicated the situation the most was that the geopolitical changes caused a debate not only about the unique nature of this fragment of a state but its international recognition as part of Russia as well.

\footnotetext{
${ }^{7}$ Laurinavičius Č., Lopata R., Sirutavičius V., Military Transit of the Russian Federation through the Territory of the Republic of Lithuania. (Rusijos Federacijos karinis tranzitas per Lietuvos Respublikos teritorija), Vilnius: Eugrimas, p. 79.
} 
When it comes to the latter issue, it was argued that the Kaliningrad region's ties with Russia had a historically defined, very limited context. What factually used to be East Prussia and Konigsberg, after World War II came into the Soviet Union's possession as a tool to guarantee the subordination of the eastern Baltic to the Soviet Union. Moscow did not have any historical rights to this territory. In other words, the question of the region was said to be inseparable from the political issue of the exclave's future, as the region's de jure subordination to the Russian Federation was not final and time-definitive (there was no sovereignty, because the Potsdam conference gave part of the East Prussian territories to the USSR to administrate pending peace regulation).

After the Iron Curtain fell, such statements were reflected by the various plans to internationalise the oblast (by way of division, condominium, ex-territoriality, decolonisation, autonomisation, independence, and so on) that appeared in the West and in the neighbouring states.

On the other hand, the debates were followed by Moscow's deliberate efforts to initiate and escalate this kind of discussion. Countries in Europe were provoked into officially abandoning plans for internationalisation. The neighbouring (intermediate) states, Lithuania first and foremost, signed treaties and agreements to guarantee Kaliningrad's viability (Rus. zhizneobespetcheniye), at the same time registering the parent country's 'special interest' in the development of the exclave. Thus the parent country sought to establish a political argument regarding an organic connection between the exclave and continental Russia and to substitute the issue of the exclave's political future with the 'technical' matters of the region's economic and social development.

Russia is very harsh in its response to any attempt to question the legal subordination of Kaliningrad.

In late January 2017, MEP Linas Balsys urged everyone to review the status of the Kaliningrad Region (KE) in response to the annexation of Crimea by Russia. Moscow's official and unofficial response was so exaggerated that Lithuania's Foreign Ministry released an urgent statement stating that the exclave was an integral part of the Russian Federation, 'however, Lithuania will continue to disregard any unilateral alterations of borders, just as it will disregard the Crimean occupation and annexation by Russia' ${ }^{8}$. Vilnius is well aware not only of how Russia responds to similar propositions, and how it initiates them as well. Let's follow a few examples.

\footnotetext{
${ }^{8}$ The Foreign Ministry reaction to L. Balsys's statements was: 'Lithuania is not raising any questions regarding the status of the Russian Kaliningrad Region', delfi.lt, 30 January 2017; Goble P. (2017), 'Is Kaliningrad on Its Way to Becoming “Russia’s Crimea”?', https://jamestown.org/program/kaliningrad-way-becomingrussias-crimea/, 22/02/2018.
} 
On the initiation. In the wake of the Maidan events in Kiev at the turn of 2013, Kaliningrad Governor Nikolai Ciukanov declared that 'Western secret services are trying to spark a second Maidan in the oblast using Poland and Lithuania as their henchmen'. The West distanced itself from this statement.

On the reaction. In early September 2016, in an exclusive interview with John Mickletwair, Bloomberg's Editor in Chief, Vladimir Putin gave an angry answer to a joke question of whether Russia would give up the Kaliningrad region. 'Well, let me be dead serious. If someone is willing to reconsider the results of World War II, let us discuss this. But then we will have to discuss not only Kaliningrad but also the eastern lands of Germany, the city of Lvov, a former part of Poland, and so on and so forth. Hungary and Romania are also on the list. If someone wants to open this Pandora's Box and deal with it, all right, go for it then.' ${ }^{10}$

By the way, in this interview Putin also stressed they would not trade the Kuril Islands either. He said he did not see any similarity between the Kuril case and the Russia-China borderline dispute over a 174 sq. m territory that Moscow handed over to Beijing in 2005. In the words of Russia's president, Russian-Chinese relations are based on a high level of trust, which is not the case with Japan ${ }^{11}$.

It needs to be highlighted that for Moscow the future of Kaliningrad has meant and still means overcoming the Potsdam tail in the relations with the West and the outcome of the Kuril subordination case in relations with Japan, or rather the impact of this case on Russia's strategy in the Far East in general.

In other words, Russia understands that absolute territorial legitimacy cannot be achieved in the Kuril Islands and, to a lesser extent, in Kaliningrad. Moscow expects to be able to resolve this problem by establishing a balance in its favour; it tries to trump the questioning of the legitimacy of the eastern borders by Japan (the US) with the China card, and of the subordination of Kaliningrad with the Western European card $^{12}$. Incidentally, this type of balance is the Kremlin's attempt not only to maintain the status quo on Russia's eastern and western flanks, but to keep the door open to its eventual victories in the fields of politics, diplomacy, spheres of influence and territorial subordination.

\footnotetext{
${ }^{9}$ Sukhankin S. (2016), „Kaliningrad: Russias Stagnant Enclave“, http://www.ecfr.eu/article/commentary_ kaliningrad_russias_stagnant_enclave_6052, 2017-06-24.

${ }^{10}$ 'V. Putin warns of World War II discussion' (2016), / https://pasaulis.lrytas.lt/ivykiai/v-putinas-ispejodel-svarstymu-apie-antraji-pasaulini-kara.htm, 25/07/2017; "We do not trade territories": Putin on Kuril Islands compromise with Japan' (2016), https://www.rt.com/news/357970-putin-japan-bloomberg-interview, 02/11/2017.

${ }_{11}^{11}$ "We do not trade territories": Putin on Kuril Islands compromise with Japan' (footnote 10).

${ }^{12}$ Lopata (footnote 1), p. 20.
} 


\subsection{Efficiency of Governance}

Attempts to neutralise the controversy over the status of the region from the perspective of international law through combinations of the balance of power have had, and still have, a direct effect on Moscow's position on the practical expression of the exclave's controllability.

The Kremlin has tried to create the image of a potentially self-sufficient subject, the Kaliningrad oblast, of the Russian Federation. Of course, the forms of practical expression of that image have been variegated.

After 1991, the trajectory of the development of the region looked quite optimistic. Its governor was the progressive, liberal-minded Yuri Matochkin (1991-1996), the oblast became home to Yantar (Amber), Europe's first free economic zone, and most of Russia's ruling elite favoured the prospect of cooperating with the West. All of that fed hopes that Kaliningrad would soon become Russia's gateway to Europe, the Baltic Hong Kong, even a fourth Baltic state. These hopes were further strengthened by various European-financed initiatives that were supposed to promote the region's socio-economic development.

The hopes and the initiatives did not bear any fruit. Kaliningrad soon became known as a 'black hole', a 'double periphery' where corruption, crime, alcoholism and AIDS (among other things) thrived.

The era of Governor Leonid Gorbenko (1996-2000) saw the establishment of the special economic zone, which became a bootleg territory. The 1998 financial crisis in Russia basically brought economic collapse to the region.

The governor and former chief of the Russian Baltic Naval Admiral Vladimir Yegorov (2000-2005) tried to look for a way out by issuing the Law on the Special Economic Zone and promoting the idea of Kaliningrad as a 'pilot region' in Russia-EU relations, an idea that was supported by the financial incentives of Euro-regional and Nordic initiatives to change the region's aspect from a planned to a market economy. This helped stabilise the region's socioeconomic lag compared to the neighbouring countries but has failed to provide a real breakthrough perspective.

These twists revealed the strategic line from Russia (Moscow): imitate the possible self-sufficiency of the region to persuade the local political elite that the federal centre has a development plan for the region and controls the internal and external levers for its implementation.

To keep the region and later use it as a tool to affect Euro-integration processes, the Kremlin only went for methods and solutions that would ensure the implementation of its strategy of choice, regardless of the extent to which 
they conformed to or contradicted the vital interests of the region.

On the other hand, to assure the legitimation of its actions, the federal centre was forced to consider a practical side as well: failure to make efforts to stimulate the development of the region with its specific situation could lead to an escalation of anti-federal sentiments. That is why government documents have always underlined the objective to ensure the development of the region as an integral part of the Russian Federation, and the federal centre has continuously tried to tackle regional problems in cooperation with local political figures. This was done in a bid to mitigate the fact that the parent country's continued attention to the province would coincide with solving one or another strategic issue that Moscow had. This statement would have an illustration both in the twists and turns relating to the fate of the specific economic regime in the region, and the expression of the role of the region's military establishment and the matters of the so-called Russian transit.

Around 2004-2005, with the so-called Kaliningrad anniversary - 750 years of Konigsberg - approaching, Russia took to modifying the geopolitical hostage model. It was obvious that it was basically leading to a stalemate situation that prevented answering the principal questions of What's next? and What will come from pumping money into a territory that has become stranded in the international environment, and keeping it on a leash?

The experience of the past decade has showed that the Kaliningrad question will not resolve itself unless the parent country finds new factors and new space to act. Since the West, Lithuania and Poland included, often demonstrated having the qualities to take over initiatives in the region from a Russia weakened by the USSR only with reference to the conjuncture, largely because the countries lacked the necessary traditions and skills. In this context, we could claim that the twists and turns of the above Kaliningrad/Konigsberg anniversary were testimony to the Kremlin having found new factors and new space.

The resolution to overcome the barrier by breaking the soviet tradition of dating back the city's history as recently as 1945 and by recognising the continuity of its history was a significant signal Moscow sent to the West. This signal got a response from the West, specifically from the key counterparty in this respect, Berlin. It should be accentuated that at the time this was more than a token gesture, of which there had been no shortage before. Now, very specific directions of cooperation between Russia and the West have made an appearance. One of these directions, the northern European gas pipeline through the Baltic Sea, soon came into everyone's view ${ }^{13}$.

${ }^{13}$ Lopata (footnote 6), p. 128-129. 
It was no accident that at the same time Georgy Boos, a robust, ambitious and open-minded politician from the parent country, was appointed the new Governor of the oblast. Not only did he open up on the region's role as a forepost for Russia and the West drawing closer together, on plans for Kaliningrad as a 'mini-state' - with the Kremlin's blessing he also took practical steps to prepare the exclave for this role. Boos himself described this role as being 'Russia's window to Europe ${ }^{\text {' }}$. In his words, instead of being a territory that Europe is trying to exploit as a preferential card on its way to Russian markets, the region should become a jumping-off ground for Russian business to integrate into European and global markets. Therefore the region needs to be modernised urgently, creating a transparent and comprehensible financial system, rendering the budget-making process public, doubling the region's energy capacity, developing the transport infrastructure and logistics, and ultimately drafting the Law on the Special Economic Zone (SEZ) so that all these measures would promote the coming of large-scale and competitive Russian capital to the region ${ }^{15}$. Boos was expecting to bring his plans to fruition by beating corruption, designing what he believed would be a different, more transparent system of motivation (privileges) and reinforcing the one-of-a-kind Russian aspect of the Kaliningrad identity.

Highlighting the latter aspect alone, tying it to the eventual migration of Russians from the heartland and the Russian-speaking populations of the Baltic countries to the exclave, was indicative of an attempt to dislodge the question of the Baltic states' Russian-speaking populations from its dead-point. Even though the ambition to maintain influence in the Baltic states using the Russian-speaking card was still there, it was not to be given any kind of priority in the face of the ongoing approach of Russia and the West. The Kaliningrad factor was thought to have the potential to become a 'passing pawn' in the complicated game of geopolitical chess between the EU and Russia. Under the conditions of a natural and open approach, this would have given a boost to the tendencies of the Europeanisation of the region's populace that could have negative political consequences for Russia. As a result, given the situation, ways were sought to increase the regional population's loyalty to Russia.

During the first few years, there were illusions that the economy might grow. Yet it soon became evident that the SEZ Law was dealing a heavy blow to small and medium-sized businesses, ignoring foreign investors. The re-import

\footnotetext{
${ }^{14}$ Lopata R. (2005), 'Kaliningrad Anniversary: the First Steps of Georgy Boss', Lithuanian Foreign Policy Review, 1-2 (15-16), p. 127-152.

${ }^{15}$ Lopata (footnote 14); Sukhankin S. (footnote 5).
} 
of European goods to the parent country that had fuelled the illusions ended as a result of the 2008 global crisis. Kaliningrad was subjected to complete control by Moscow and the region's economy basically became dependant on financial subsidies from the parent country.

The global economic crisis showed that the federal centre was unable to subsidise the region the way it had before the crisis. After Moscow called for new 'interior resources', Boos decided to raise taxes (for instance on the trade in second-hand cars, the most popular kind of small business), reduce spending on healthcare and so on. This prompted some dissatisfaction among the Kaliningradites, and the mass protests of 2009-2010 were dubbed the Orange Spring. The reference to the Orange Revolution in Ukraine ignited talks about an approaching victory of democrats in Kaliningrad and about Kaliningrad becoming a Russian Gdansk ${ }^{16}$. These rumours were premature.

The protests in Kaliningrad were sparked by political and value-based beliefs just as they were by pragmatic and economic motives ${ }^{17}$. The protests broke out because Moscow was unable to deliver on its promises to subsidise Kaliningrad. Moscow's reaction was: It wasn't my fault. The region's government was replaced, the taxes recalled, subsidies to maintain 'viability' granted. The situation stabilised, if only for a while.

The sanctions the West imposed on Russia after the annexation of Crimea hit Kaliningrad as well. The stagnant socio-economic development was also affected by the expiry of the Special Economic Zone's status on 1 April 2016. This had an effect on nearly 800 businesses within the region that provided jobs to a quarter of Kaliningrad's population. Of course, Moscow rushed to make a 66 billion rouble grant as compensation for the loss of the SEZ and promised to draft a new law on Kaliningrad's socio-economic development ${ }^{18}$. This was enough to guarantee a landslide victory for the United Russia (Yedinaya Rossiya) party in elections to the National Duma, the Duma of the Kaliningrad region and municipal councils that took place in the oblast on 18 September 2016, despite opposition representatives predicting before the elections that United Russia would be unable to gain more than $50 \%$ of the votes. A total of 27 members of the ruling party were elected to the Kaliningrad Duma of 40 seats $^{19}$, a qualified majority. The so-called non-systemic, independent oppo-

\footnotetext{
${ }^{16}$ Sukhankin S. (2017), 'Baltic Hong Kong No Longer', https://www.fpri.org/article/2017/04/kaliningradbaltic-hong-kong-no-longer/, 02/05/2017.

${ }^{17}$ Sukhankin S. (footnote 9).

${ }^{18}$ Sukhankin S. (footnote 9).

${ }^{19}$ Vybory 2016 (2016), Dvornik, 27/09/2016, No 37 (1043), http://pressa-online.com/ ws.aspx? service=issue-file-download\&iid $=193814,09 / 11 / 2017$.
} 
sition only won a single mandate. Yet Igor Rudnikov, the managing editor of Novye Kolesa who achieved this, was put into custody in 2017 and prosecuted on charges of extortion over a bribe.

A new law on the socio-economic development of Kaliningrad was signed by Putin on 5 December $2017^{20}$ and came into effect on 1 January 2018. The law provides for new additional privileges to SEZ residents in the form of reduced social insurance contributions, a lower investment threshold in the IT and medical sectors, a simplified procedure for issuing visas to foreigners, a larger SEZ territory to cover both the region's inland waters and the Russian part of the Baltic Sea.

The way the votes of the Kaliningrad electorate went in the presidential elections of the Russian Federation of March 2018 hardly needs explaining. Putin's visit to the region on the eve of the elections is a matter of some eloquence $^{21}$. During his visit, he ceremonially inaugurated two thermal plants and said that it was the first serious step towards ensuring Kaliningrad's energy security. Afterwards, he attended the region's media forum where he praised the developers of Avangard, a strategic missile unit. They say that one of those present at the ceremonies recalled the words of Patriarch Kirill, who referred to Kaliningrad three years prior as a lighthouse and citadel of the 'Russian world' in Europe.

\subsection{The Exclave's Military Function}

This is a hot topic in Kaliningrad studies today. The most frequent question is this: How did the Kaliningrad region 'return' to the Soviet Union area to become a military bastion, the Russian A2/AD 'bubble', probably the most militarised region in Europe?

It did not happen overnight - although that was what it took to replace the entire command of the Russian Baltic Navy.

Formally, the purpose of the military function is to strengthen the guarantees of Kaliningrad's subordination to the Russian Federation from both an internal and external perspective.

In terms of the internal perspective, the prior level of militarisation of the region also allowed Moscow to control the conduct of the region's political elite.

\footnotetext{
${ }^{20}$ Administracija Prezidenta RF // http://www.kremlin.ru/acts/news/56303, 04/02/2018.

${ }^{21}$ Выползов А. (2018), 'Панихида по энергоблокаде и агрессии Литвы: Путин в Калининграде', https://regnum.ru/news/polit/2386788.html, 03/03/2018.
} 
For instance, the restriction and revocation of the Free Economic Zone regime in the region in 1994-1995 was followed by the establishment of a defence district under the Commander of the Russian Baltic Navy, directly subordinate to the Defence Ministry and General Staff.

In the 2000 Kaliningrad gubernatorial elections, for all practical purposes the Kremlin bluntly supported Commander of the Russian Baltic Navy Admiral Yegorov who was popular with the local political elite yet also loyal to Putin (so far he has been the only admiral-governor in the history of the Russian Federation).

At the close of 2005, the command of the Baltic Navy with Vladimir Valuyev at its helm issued a rather explicit warning to the new governor, Boos, that the region's military elite frowned on efforts to strengthen the region's economic and cultural cooperation with foreign states, allegedly creating the conditions for a voluntary segregation of the Kaliningrad region from the Russian Federation.

In the meantime, if we look at it from the external perspective, the region's military potential has been a tool the Kremlin used in its dialogue with Western Europe (the US) over the upkeep of the balance of power. In this sense, the restraining function of the Russian military factor eventually trespasses on the limits of the region, covering the eastern Baltics as a minimum. For instance, in 1993-1995 and in the spring of 2001, Moscow tried to exploit the matter of Russias military transit to/from Kaliningrad through Lithuania, its aim being not only to stall the process of Lithuania's NATO integration in the hopes of keeping Lithuania within its zone of its influence through the political agreements needed to legalise the transit, but also to control the whole process of the eastward expansion of Western structures and affect the geopolitical situation in Central and Eastern Europe in doing so ${ }^{22}$. Notably, during the above periods France, and Germany in particular, would symptomatically adopt a stance of non-interference and even favour Russia in regard to these tendencies.

In early 2001, The Washington Times and The Daily Telegraph reported that the Russians were deploying nuclear weapons in Kaliningrad. Moscow furiously denied the reports, even though an influential Kaliningrad political figure at the time made a comment in jest: Why deploy anything when the weapons have never been removed?

It looks like the reports were an attempt to remind the world that the

\footnotetext{
${ }^{22}$ Laurinavičius Č., Lopata R., Sirutavičius V. (2002), „Rusijos Federacijos karinis tranzitas ị/iš Kaliningrado srities per Lietuvos teritoriją", Politologija, 4, p. 3-35.
} 
Zapad-99 exercise that took place in Kaliningrad in April 1999 included a socalled de-escalation scenario. It involved using nuclear weapons to overpower NATO's conventional weapons systems. This was documented in detail in Russia's new national security concept and military doctrine as well. In this context, the Brits have issued reports on certain alleged Russian-German pacts at the expense of Kaliningrad ${ }^{23}$. This caused quite a turmoil and have resulted in a great many interpretations. Yet Moscow's response to them was ostentatiously calm, as if it had merely stroked Russia's ego that it could unilaterally decide the fate of the Baltic region too.

Finally, in February 2007, the world was shaken by Putin's speech titled 'Russia in Global Politics' delivered at a security conference in Munich. In it, Russia's president generously criticised the US and the West and NATO's expansion and stressed that Moscow was prepared to use the Kaliningrad factor against $\mathrm{NATO}^{24}$. This was but a prelude.

After the war with Georgia, circa 2009, Russia took serious organisational measures as well as steps to muster its military forces. These extended to Kaliningrad, which had become a formidable military bastion by 2016 .

First of all, the Kaliningrad factor was used in Moscow's so-called Iskander diplomacy, by threatening to deploy or temporarily deploying mobile Iskander ballistic missiles. For instance, in October 2016 Russia’s Defence Ministry declared that within the framework of military readiness, missile units armed with Iskanders had been repeatedly deployed in the Kaliningrad region and that there were no plans to discontinue the practice in future ${ }^{25}$. In mid-February 2018, Lithuanian President Dalia Grybauskaite and Defence Minister Raimundas Karoblis reported the deployment of short-range Iskanders in the Konigsberg region. In the words of Karoblis, Russia had previously shipped the missiles for training, but 'this time the situation is different: it is a permanent deployment with all the necessary infrastructure ${ }^{36}$. Both Lithuania and other NATO countries and the Alliance's command voiced its concerns. Vladimir Shamanov, Chairman of the Defence Committee of the Russian State Duma, only scoffed saying that Kaliningrad was 'our legitimate territory, we do as we please, in opposition to they (NATO) who invite the Americans and others who are hostile towards us ${ }^{27}$. Shamanov appealed to the so-called security di-

\footnotetext{
${ }^{23}$ Sirutavičius V. (2002), „Maskvos eksperimentas virsta ant kaklo veržiama kilpa“ žr.: Lopata R., Laurinavičius M., eds., Tarptautiné politika: komentarai ir interpretacijos, Vilnius: Eugrimas, p. 256.

${ }^{24}$ JAV ir Europa nuvyle V. Putino kalba Miunchene (2007), delfi.lt, 12//02/2007.

${ }_{25}$ Šalia Karaliaučiaus gali büti dislokuoti nauji Rusijos raketiniai kompleksai (2017), delfi.lt, 02/12/2017.

${ }^{26}$ Rusija apie veiksmus Lietuvos pašonejje: ka norim, tą ir darom (2018), delfi.lt, 15/02/2018.

${ }^{27}$ Rusija apie veiksmus Lietuvos pašoneje: ką norim, tą ir darom (footnote 26).
} 
lemma and the fact that in 2015 Russia stepped down from the Treaty on Conventional Armed Forces in Europe (CFE).

Notably, the Russians had been preparing thoroughly, and the continued efforts to raise military readiness in the Zapad strategic exercise (in 1999, 2009, 2013 and 2017) were there to prove it. The rearming of the armed forces in Kaliningrad was progressing consistently ${ }^{28}$. Finally, organisational measures were taken and the entire command of Russia's Baltic Navy was replaced overnight. Considering all of Russia's measures to develop its military that have been applied in the Western Military District, it is safe to say that in 2015-2016 Moscow achieved total superiority of its conventional weaponry over NATO ${ }^{29}$. Kaliningrad played a vital role in this process.

Given these developments, we may yet live to see a strategically new perspective for the Kaliningrad region. Not only has Kaliningrad become a Russian $\mathrm{A} 2 / \mathrm{AD}$ 'bubble'; it is now also a factor undermining the strategic geopolitical role of Belarus. Clearly, the rapid remilitarisation of Kaliningrad has challenged not only regional states but transatlantic relations as well, something that became evident from a visit by the three Baltic presidents to Washington in early April 2018.

The Kaliningrad region is indeed becoming a geopolitical link under Russia's control; the exclave is geopolitically tied to Russia and plays a key part in its strategic relations with the West.

Incidentally, the connection between Kaliningrad's remilitarisation and the situation in the Kuril Islands is also worth paying attention to. Back in the summer of 2011, when France and Russia signed an agreement whereby France committed itself to building two Mistral-type landing craft for Russia’s Defence Ministry, Defence Vice-Minister Vladimir Popovkin said that Moscow would use one ship to defend Kaliningrad, and the other the Kuril Islands ${ }^{30}$. After Russia invaded Crimea, Paris refused to sell the Mistrals to Moscow. Yet the Kremlin has not abandoned the idea of boosting its military presence in the Kurils.

In 2016, Russia modernised the military infrastructure on the islands and started deploying additional military personnel. In early 2017, Moscow

\footnotetext{
${ }^{28}$ Ivanauskas V., Keršanskas V., Kasčiūnas L. (2016-2017), 'Kaliningrad Factor in Lithuanian - Russian Relations: Implications to the Security Issues of Lithuania', Lithuanian Annual Strategic Review, vol. 119-149. ${ }^{29}$ Sukhankin S. (footnote 5); Westerlund F. (2017), 'Russia’s Military Strategy and Force Structure in Kaliningrad', https://www.foi.se/download/18.bc6b81b15be852194d71d/1494413062692/RUFS\%20Briefing\%20 No\%2040\%20Kaliningrad\%20by\%20Fredrik\%20Westerlund.pdf, 23/05/2017.

${ }^{30}$ ‘Can We Rule Out a New Pearl Harbour?' (2011), https://orientalreview.org/2011/08/10/can-we-ruleout-a-new-pearl-harbour/, 06/12/2017.
} 
declared plans to build a military naval base and launched construction at the end of that year. In early 2018, Prime Minister Dmitry Medvedev admitted to the presence of military aircraft in the Kuril Islands ${ }^{31}$. In response to regional concerns, Putin declared that Russia's military activity in the islands had to do with America's military activities in the region. According to him, it was not Russia's own initiative but rather a response to the US's military activities in South-East Asia. The president admitted that even though negotiations with Japan over joint projects on the Kuril Islands were underway, Moscow had no plans to surrender them. In his opinion, if Russia took a step like that, the Japanese would not be the only ones to arrive; US troops would soon be there too. Putin appealed to the Japan-US Status of Forces Agreement (SOFA) that envisaged such a possibility ${ }^{32}$. Ergo, the Kuril Islands too are being treated as a geopolitical tool against the US, one that is designed to increase Russia's strategic influence in the Far East, South-East Asia and the Pacific Rim.

\section{The Factor of other States and International Institutions in the Kaliningrad Problem}

After the end of the Cold War, a lot of Western countries took an interest in the Kaliningrad problem. It should be noted that virtually none of them would remind Russia of the complicated aspects of the legal and political status of the region or try to raise any suspicions of an escalation in the separatist tendencies within the region. Despite the West trying to justify its stance with efforts not to alienate and later structurally tie Russia to the West, the position gave Moscow freedom of manoeuvre to balance its forces on its western flank, replacing the political and legal problem of escalation with the 'technical' matters of the region's economic and social development and ensuring that the West and the EU would only be able to voice their opinions on Kaliningrad

\footnotetext{
${ }^{31}$ Southgate L. (2018), 'An old dispute re-emerges as Russia militarises Kuril Islands', https://globalriskinsights.com/2018/03/japan-russia-dispute-northern-territories/, 2018-04-02; 'Russia Starting Construction of Naval Base in Kuril Islands' 30/11/(2017) // http://www.navyrecognition.com/index.php/news/defencenews/2017/november-2017-navy-naval-forces-defense-industry-technology-maritime-security-globalnews/5761-russia-starting-construction-of-naval-base-in-kuril-islands.html, 2017-12-05; 'Russia Approves Deployment of Warplanes in Kuril Islands' (2018), https://themoscowtimes.com/news/russia-aprovesdeployment-of-warplanes-in-kuril-islands-60381, 03/02/2018.

${ }^{32}$ Taishu Pitt J. (2017), 'The Third Annual Eastern Economic Forum and the Japan-Russia Summit', https:// thediplomat.com/2017/09/the-third-annual-eastern-economic-forum-and-the-japan-russia-summit/, 08/09/2017; Gady F.-S. (2017), 'Putin: Russian Force Buildup in Kuril Islands a Response to US Military Actions', https://thediplomat.com/2017/06/putin-russian-force-buildup-in-kuril-islands-a-response-to-usmilitary-actions/ 05/06/2017.
} 
with Moscow knowing about it. Eventually the 'modesty' of the West allowed Russia, in its bid to draw a straight geopolitical line between Moscow and Kaliningrad, to use it as an instrument (for instance in demanding special decisions on the viability of the region as an integral part of the Russian Federation) to halt the structural expansion and integration of the West, in other words to turn the exclave into a hostage of East-West relations.

The neighbouring (host) states, Lithuania and Poland, tried to question Kaliningrad's geopolitical formula, showing a great deal of interest in the position of the region, especially during periods of making and implementing their own decisions on their gravitation towards the West. They repeatedly tried to draw the West's attention to the Russian foreign policy strategy of revising the balance of power that took shape under the influence of Euro-Atlantic integration based on the model of the concert of the great states, complaining that this was being done at the expense of the interests of the host countries and that the Kaliningrad problem might be used in this manner.

In doing so, Lithuania managed to secure the support of the US and the UK in withstanding Russian pressure to legalise the military transit through its territory in 1993-1995 and in 2001. The European Commission and several Nordic states gave their approval to the paradigm of turning the Kaliningrad problem into an advantage as formulated also by Vilnius in 1998. Notably, the paradigm was initially fine with Moscow, which at the turn of the century saw Lithuania's membership in the EU as a distant future prospect and was concerned rather with driving a wedge between the US and Europe and developing mutual relations with the major EU states.

However, as it gradually realised it had made an error in its assessment of the extent and the speed of Euro-Atlantic integration, Moscow openly transitioned to balancing conflict. Claiming that EU expansion with regard to Kaliningrad was an exterior development that made Brussels responsible for the adaptation of this Russian Federation region and its connection with Russia, it tried to alter the structure of the dialogue over the development of Kaliningrad, eliminating the 'intermediaries' and negotiating the matters of the exclave directly with the major EU states and Brussels.

In a bid to neutralise the impact of the Russian factor on the national interests of Euro-Atlantic integration, Poland and Latvia were inclined to reduce their engagement in this dialogue. Proclaiming themselves as 'non-transit' countries, they basically made it easier for Russia to focus on just one target, the territory of the Republic of Lithuania.

By compromising Vilnius as an obstacle in the way of the exclave's de- 
velopment, Moscow demanded exterritorial corridors and other preferences for the Russian factor on Lithuania's territory. In the meantime, Russia used its mutual relations with the major EU states to pressure and openly blackmail the European Commission into securing privileges and compensations for all of the Russian Federation's citizens, and after the expansion of the EU demanded a special format for negotiating the matters of the Kaliningrad region.

The Western states did not dare remind Russia that the question of the status of Kaliningrad - the renouncement of the principles of law for the sake of alleged benefit and the resulting submission to the principle of force - had not yet been resolved in terms of international law. A 'flexible' solution was adopted, replacing the political problem with 'technical' questions of the region's economic and social development straight away. The 'modest' decorum of the West, the unwillingness to bring to attention the political and the legal aspects of the region's status, ended, just as could have been expected, in a 'policy of power', with pressure and even blatant blackmail on Russia's part.

The diplomatic relations between Russia and the EU showed that the former formally accepted the rules of the relations as proposed by the latter ${ }^{33}$. Brussels refused to assume political responsibility for the development of the region and only agreed to focus on the problems caused by the direct procedural consequences of EU expansion, and did not say 'no' to making European funds available to basically ensure the exclave's economic growth on Russia's terms.

Still, an essentially new outlook for the Kaliningrad region, one that would keep the exclave close to the parent country and project the function of an active Russian geopolitical dummy in the space of European integration, was opened by Moscow's direct strategic contact with the West, specifically with Berlin, the key counterpart in this context. Specific manifestations of this contact could be observed earlier, and they can be seen today as well (Nord Stream I and II). On the other hand, such steps on the EU's part could be construed as an attempt to 'tie' Russia to Europe.

After the occupation of Crimea the situation changed. Sanctions against Russia are being tightened. Kaliningrad and the military potential deployed within it are seen as a Russian tool for dialogue with the West on maintaining the balance of power ${ }^{34}$. However, one should not rule out the possibility that, should the international circumstances change, Kaliningrad could again become a 'passing pawn' in the geopolitical chess game between Russia and

\footnotetext{
${ }^{33}$ Lopata (footnote 6), p. 107-115.

${ }^{34}$ Westerlund F. (footnote 29).
} 
the West. Moscow could be forced to rethink its policy through visa-free regime negotiations with the EU (with Kaliningrad becoming a 'pilot region' in this process), or by negotiations between the EU and the Eurasian Economic Union on a free economic space 'from Lisbon to Vladivostok'.

It should also be noted that, despite the sanctions and what would seem to be an unfavourable socio-economic environment, Germany (BMW) and Lithuania (fertiliser manufacturers) are still willing to invest in Kaliningrad.

\section{Securing a Connection between Exclave and Parent Country (Matters of Military, Passenger and Goods Transit)}

To prevent the exclave from becoming isolated from Russia's continental territory and to secure additional safeguards to ensure its subordination and increase Russian influence on the integration processes of the EU, Moscow has been known to employ other methods as well. Manipulating the idea of the exclave as a 'pilot region', it took to strengthening the mechanisms of the centre's control over the region.

Considering that after the Cold War many of the predictions regarding Kaliningrad have not come true, and Russia's various plans to modernise the region have not been brought to fruition for different reasons, it is likely that Moscow, in a bid to increase the region's subordination, will rely more on traditional measures to secure subordination by strengthening the connection between the exclave and the parent country.

Traditionally, Russia has sought to secure this connection through Lithuania’s territory, exploiting the issues of military, passenger and goods transit.

The matter of Russian military transit to and from Kaliningrad through Lithuanian territory carried the highest degree of sensitivity and caused a lot of tension between Moscow and Vilnius. The essence of the problem is that Russia tried to procure specific conditions for its military transit across Lithuania, attempting to legitimise the transit by factually granting it settlement status. Lithuania, however, saw such Russian foreign policy endeavours as a threat to its sovereignty and NATO integration. As a result, a compromise was made and, while Moscow did not lose its ability to use the transit territory, Lithuania preserved its sovereignty as well ${ }^{35}$. The established procedure for Rus-

${ }^{35}$ Laurinavičius Č., Lopata R., Sirutavičius V. (footnote 22), p. 30-35. 
sian military transit did not obstruct Lithuania's integration into Euro-Atlantic structures. This, however, does not mean that Moscow is not trying to question the procedure and may resort to provocation, for instance should tensions in relations with individual Euro-Atlantic states and institutions escalate.

The question of the transit of Russian Federation citizens to and from the Kaliningrad region was also resolved by way of compromise. Of course, this matter was settled with the involvement of both Lithuania and Russia, and the EU. The transit of Russian passengers through Lithuanian territory is not a matter of any threat and is under control, at least for now. Yet this does not mean that Moscow would be unwilling to use this transit as an instrument of provocation.

Despite Russia's efforts to specifically institutionalise the question of goods transit to and from Kaliningrad, decisions on this type of Russian transit are limited to a technical level and, as often as not, depend on the character of EU-Russia relations.

Right now, one of the puzzles that Moscow has to deal with is providing the region with energy resources. After the Baltic countries become desynchronised from the so-called BRELL ring, the Kaliningrad region will no longer be part of this energy system either and will have to operate independently. The inauguration of new heat and power plants in the region in early 2018 shows that Moscow is making serious preparations for this. During the opening ceremony, Inter RAO's chairman of the board stated that the plants have been designed to 'secure a reliable supply of electricity to Kaliningrad's energy system once it enters the stand-alone mode ${ }^{36}$. Moscow is preparing to keep Kaliningrad's energy system isolated.

This is evident from energy plans that provide for the construction of several more heat plants and a liquefied gas terminal, as well as for the development of oil extraction in the Baltic Sea. Lukoil has announced that it will start building yet another platform (D41) and has plans for new oil wells near the Curonian Spit (D18 and D19). It looks like these plans were reflected in a new law on the socioeconomic development of the Kaliningrad region that Vladimir Putin has signed. Among other things, the law expands the SEZ territory to include Kaliningrad's inland waters and the Russian part of the Baltic Sea. Neither will Moscow forget the Nord-Stream II project and the scheduled gas branch to the region.

Returning to transit, it is important to highlight that the parent country is making a lot of efforts to tie all types of transit together. In doing so, it is trying to have the specific passenger regime applied to goods transport, and

\footnotetext{
${ }^{36}$ Energetikos ministras: Rusija ruošiasi Baltijos šalių elektros tinklų atjungimui (2018), delfi.lt, 3 March 2018.
} 
eventually also to the military transit to and from Kaliningrad via Lithuanian territory. On the other hand, the energy projects as well as projects, for instance, related to transport infrastructure (building and reconstructing highways, the reconstruction and development of Khrabrov Airport, the construction of an international cruise ship and cargo terminal in Pionersk, the modernisation of the infrastructure of the existing Kaliningrad port, building new ferries for the Kaliningrad-Ustluga line) show that Moscow will continue to make every effort to keep Kaliningrad viable against the background of isolation and transit restrictions (termination).

\section{Conclusions}

In conclusion, it needs to be emphasised that since the Cold War Moscow has consistently upheld tension with regard to two of its strategies on the Kaliningrad region (zagranitchnaya Rosiya, or 'foreign Russia'). Strategy number one focuses on the role of the exclave as Russia's military forepost geared towards expanding the influence of the jumping-off point and/or hamper the influence of the West, depending on the circumstances. Strategy number two sees the exclave as a testing ground for economic reforms that could have become a geopolitical tie to link Russia and the West thanks to its favourable geographical location.

During some periods, there has been a rather justified hope that Moscow will gradually transition to a vision of Kaliningrad as a testing ground for economic reforms. Even diplomatic documents negotiated between the West and Russia used to refer to it as a 'pilot project', and Moscow itself would eagerly feed the region hopes of a new political and special economic status as compensation for it being an exclave. Of course, today it is obvious that at the time Moscow factually had no strategic plan to ensure stable socio-economic development for the region and failed to grasp the extent and speed of international processes, Euro-Atlantic integration first and foremost, straight away. Since the West did not have a strategic vision for the region, this gave Moscow space to manoeuvre for balancing power on the so-called western flank, and allow it to replace the political problem of the exclave with the 'technical' matters of the region's socio-economic development and ensure that Western states would only be able to express their opinion on Kaliningrad with Russia's knowing about it. That way, the Kremlin realised that the Euro-Atlantic integration processes could be harnessed for its own benefit.

Roughly fifteen years ago, Moscow reached a decision that the region's dramatic lag behind its neighbours, Poland and Lithuania in particular, could 
become disastrous. Attempts were made, therefore, to look for new instruments and new space to act. Federal funds were thrown in to 'stabilise' the economic gap between the region and its neighbours and Kaliningrad was proclaimed to be Russia's window to Europe, meaning that the region should not be a territory that the Europeans are trying to exploit as a preferential card to penetrate Russian markets, but rather a jumping-off ground for Russian business to integrate into European markets. Efforts were made to modernise the region's governance, and a decision was even made to break the tradition of dating Kaliningrad's history back only as far as 1945 and recognise the continuity of its history. Furthermore, the EU's financial support was gladly welcomed for reallocation in Moscow.

So in real diplomatic practice, Kaliningrad became a pledged item used in the strategic exchanges between Russia and the West, exchanges based on tactics of deterrence (suppression) - pacification and engagement. By 2004, the region had been turned into a geopolitical hostage, a territory grabbed in the process of cession as the spoils of war not only for it to be kept but also for other countries and international institutions to be made to abstain from any direct or indirect act of liberating the hostage. At the same time it meant that the course of transformation for the exclave as a geopolitical hostage would also depend on whether Russia's politics would allow the federal centre to use it as a jumping-off point to increase its influence in the EU to an extent greater than Kaliningrad becoming open to the EU.

It should be stressed that Moscow connects the matter of Kaliningrad's future both to overcoming the Potsdam tail in its relationship with the West and to the case of the Kuril Islands' subordination in dealing with Japan and the influence that case has on Russia's strategy in the Far East. Russia has realised that no absolute territorial legitimacy can be achieved either in the Kuril Islands or in Kaliningrad, albeit to a lesser degree. Moscow has been and still is hoping to resolve this problem by establishing a balance in its favour; it has tried to trump the questioning of the legitimacy of the eastern borders by Japan (the US) by using the China card, and of the subordination of Kaliningrad with the Western European card. This type of balance was the Kremlin's attempt not only to maintain the status quo on the western and the eastern flanks but to keep the door open for its eventual victories in the fields of politics, diplomacy, spheres of influence and territorial subordination.

Following the West's perceived expansion in Central and Eastern Europe, academia's attention to Russia's balancing leveraged with the Kaliningrad factor has waned. Yet the shift in the balance of power in the pan-Baltic region 
in the wake of Russia's military intervention in Ukraine makes us rethink the political, economic and military status of Kaliningrad, as well as its place in the new security architecture.

Moscow has tightened its grip on the social, economic and political processes in Kaliningrad. By using financial subsidies, infrastructural projects and laws to modify the status of the exclave, the parent country is trying to stabilise the socio-economic situation there, making every effort to ensure Kaliningrad's viability under isolation and transit restrictions (termination). Political control is assured by Moscow's direct dummies within the exclave's administration and United Russia's dominance in the so-called elected institutions.

After the war with Georgia, which is to say roughly since 2009, Russia has taken serious organisational measures as well as steps to muster its military. These also extend to Kaliningrad, which had already become a formidable military bastion before 2016. Considering the measures Russia deployed to develop its military presence in the Western Military District, we can say that in 2015-2016 Moscow attained complete superiority of conventional weaponry over NATO. The Kaliningrad region played a vital role in that process.

Given these developments, we may yet live to see a strategically new perspective for the Kaliningrad region. Not only has Kaliningrad become a Russian $\mathrm{A} 2 / \mathrm{AD}$ 'bubble' raising security concerns for the Baltic states and Poland, it is now also a factor undermining the strategic geopolitical role of Belarus. Clearly, the consistent remilitarisation of Kaliningrad has challenged not only regional states but transatlantic relations as well. To Moscow, the military potential of the exclave is a tool in the strategic dialogue with the West over the upkeep of the balance of power. Notably, Moscow treats the factor of the remilitarised $\mathrm{Ku}-$ ril Islands as a geopolitical tool against the US, one that is designed to increase Russia's strategic influence in the Far East, South-East Asia and the Pacific Rim.

However, one should not rule out the possibility that, should the international circumstances change, Kaliningrad could again become a 'passing pawn' in the geopolitical chess game between Russia and the West. Moscow could be forced to rethink its policy by visa-free regime negotiations with the EU (with Kaliningrad becoming a 'pilot region' in this process) or by negotiations between the EU and the Eurasian Economic Union on a free economic space 'from Lisbon to Vladivostok' (quite possibly, the function of the Kuril Islands would depend on the growing need for Russia to reduce its dependence on China, using it as leverage against Japan) and other factors. 